\title{
Disinfection of urines using an electro-ozonizer
}

Miguel Herraiz-Carboné ${ }^{1}$, Salvador Cotillas ${ }^{1 *}$, Engracia Lacasa ${ }^{1}$, Pablo Cañizares $^{2}$, Manuel A. Rodrigo ${ }^{2}$, Cristina Sáez ${ }^{2 *}$

${ }^{1}$ Department of Chemical Engineering, Higher Technical School of Industrial Engineering, University of Castilla-La Mancha, Edificio Infante Don Juan Manuel, Campus Universitario s/n, 02071 Albacete, Spain

${ }^{2}$ Department of Chemical Engineering, Faculty of Chemical Sciences and Technologies, University of Castilla-La Mancha, Edificio Enrique Costa Novella, Campus Universitario s/n, 13005 Ciudad Real, Spain

*authors to whom all correspondence should be addressed (corresponding authors): cristina.saez@uclm.es; salvador.cotillas@uclm.es .Tel.: +34-926-29-53-00 Ext.6708 


\begin{abstract}
In this work, the disinfection of urines polluted with Klebsiella pneumoniae ( $K$. pneumoniae) using a commercial electro-ozonizer is described. The device consists of a membrane-electrode assembly flow cell that specially promotes the electrochemical generation of ozone. Results show that a complete disinfection is attained in less than 180 min when working at current intensities higher than $0.5 \mathrm{~A}$. The higher the current intensity, the higher the disinfection rate. Furthermore, the use of an electro-ozonizer for treating diluted urines leads to higher disinfection efficiencies. Ozone and chlorine-based disinfectants (hypochlorite and chloramines) were identified as the main oxidant species involved in killing bacteria. The combined effect of all disinfectants promotes higher removal efficiencies in comparison with the single effect of ozone evaluated in a urine matrix without chlorides, being more remarkable at lower current intensities. The crystal violet assay showed that cell wall is damaged by the electrogenerated oxidants and it is more remarkable by the combined effect of ozone and chlorine disinfectants when increasing the current intensity. Finally, the degradation of total proteins and genetic material (DNA) were also monitored and related to the oxidants produced during the electrochemical process.
\end{abstract}

\title{
Keywords
}

Ozone; electrodisinfection; electro-ozonizer; antibiotic resistant bacteria; DNA 


\section{Highlights}

- K. pneumoniae is completely removed from urines using a MIKROZON® reactor.

- Ozone and chlorine-based disinfectants are the main species involved in the process.

- Proteins are mainly degraded by the combined effect of all disinfectants.

- Ozone promotes the degradation of DNA during disinfection of urines. 


\section{Introduction}

Nowadays, the pandemic caused by coronavirus has aroused a further interest in ozonebased systems for disinfection purposes to stop the transmission of virus in aquatic bodies $[1,2]$. For this reason, ozone generation has become a hot topic for scientific community. Ozone is mainly generated by the corona discharge method which consists of passing an oxygen stream between two electrodes separated by a dielectric material, ground electrode and high-voltage electrode, where an electric discharge is applied [3]. Oxygen molecules are dissociated in atoms under the electric field in a first stage and then, these oxygen atoms react with non-dissociated oxygen molecules, producing ozone. There exist another methods for ozone generation such as the irradiation of UV light [4], the use of energy radiation [5] or the electrolysis process [3]. This last method has been studied in depth for wastewater treatment [6-8] since it does not only promotes the generation of ozone from water electrolysis but also it can produce large amounts of powerful oxidants from the oxidation of the ions naturally contained in wastewater, depending on the electrode material and the operating conditions [9]. This explains the high efficiencies attained in the removal of organics or disinfection with this process $[10,11]$. However, the main drawback of using ozone in wastewater treatment is the mass transfer limitation from gas to the liquid phase [12]. In this context, novel solid-electrolyte electrolyzers have been developed [13], in which ozone is directly produced in the liquid phase, avoiding limitations in the transport from the gaseous to the liquid phase and, hence, increasing the efficiency of the degradation processes [14, 15].

Ozone $\left(\mathrm{O}_{3}\right)$ is a powerful oxidant $\left(\mathrm{E}^{0}: 2.07 \mathrm{~V}\right)$ that has been widely used for the removal of organic pollutants in wastewater [16]. It is easily decomposed to hydroxyl radicals at alkaline conditions, favoring the complete mineralization of organic matter [17]. As disinfectant, ozone is more effective than chlorine systems for killing microorganisms 
(bacteria, viruses or fungi) since its oxidation potential is higher than hypochlorous acid $\left(\mathrm{E}^{0}: 1.49 \mathrm{~V}\right)$ or chlorine $\left(\mathrm{E}^{0}: 1.36 \mathrm{~V}\right)[18]$. For this reason, it has been used for the removal of antibiotic resistant bacteria (ARB) and antibiotic resistant genes (ARGs) in wastewater since this microbiological pollution is considered as one of the main challenges that should be faced by the researchers in the coming years due to its hazardousness [19]. Oh et al. [20] compared the efficiency of electron beam, chlorination and ozonation processes on the removal of ARB and ARGs, finding that it was needed chlorine doses of $30 \mathrm{mg}$ $\mathrm{dm}^{-3}$ to remove over $90 \% \mathrm{ARB}$ and ARGs whereas only $3 \mathrm{mg} \mathrm{dm}^{-3} \mathrm{O}_{3}$ led to the removal of more than $90 \%$ ARB and ARGs. More recently, the removal of ARGs by chlorination, UV and ozone has been reported by Stange et al. [21]. They concluded that similar inactivation rates for ARB and ARGs were only obtained with $1 \mathrm{mg} \mathrm{dm}^{-3} \mathrm{O}_{3}$. For UV and chlorine disinfection processes, the ARB depletion was observed at lower doses, but it was not possible to remove ARGs during UV disinfection and higher chlorine doses than $1 \mathrm{mg} \mathrm{dm}^{-3}$ are required to ensure the removal of ARGs.

With this background, the main aim of this work was to evaluate the application of a commercial solid-electrolyte electro-ozonizer (MIKROZON®) for the disinfection of urines, paying special attention to the role of electrogenerated oxidants, including ozone, on the process performance. The main mechanisms for killing bacteria were evaluated to gain insight into the contribution of ozone or chlorine disinfectants on the cell damage. Urine was selected as case study, because of its hazardousness, since the concentration of ARB in this type of effluents is higher than that found in wastewater [22]. Furthermore, to the authors' knowledge, the disinfection of hospital urines using an electro-ozonizer with solid-electrolyte technology has not been reported yet, and it is a topic of great interest due to the complexity of this effluent. Klebsiella pneumoniae was selected as ARB model and, the electrolysis of urines polluted with this bacterium were carried out 
applying current intensities within the range 0.1-1.0 A. This will allow us to evaluate not only the disinfection process but also the influence of the current intensity on the disinfectants production and their relationship with the disinfection mechanism.

\section{Material and methods}

\subsection{Chemicals and bacteria}

The formulation of synthetic urine (urea, creatinine, uric acid, potassium chloride, magnesium sulfate, calcium phosphate, sodium carbonate, and diammonium hydrogen phosphate) was based on analytical grade compounds and used as received (Sigma Aldrich, Spain). Chemicals used for the measurement of chloramines were potassium phosphate monobasic, sodium phosphate dibasic, ethylenediaminetetraacetic acid (EDTA), N,N-Diethyl-p-phenylenediamine sulfate (Sigma Aldrich, Spain), and sulfuric acid (VWR). Acetone, sodium carbonate, 2,6-pyridinedicarboxylic acid, and nitric acid (Sigma Aldrich, Spain) were employed for the determination of ions concentration. The determination of hypochlorite ion required arsenic trioxide (Sigma Aldrich, Spain) and sodium hydroxide (Panreac, Spain). Crystal violet dye (Sigma Aldrich, Spain) was used for the evaluation of the cell wall damage. All chemicals were analytical grade and used as received. The bacterial strain used during the electrodisinfection processes was K. pneumoniae ATCC 4352 (CECT, Spain). Double deionized water (Millipore Milli-Q system, resistivity: $18.2 \mathrm{M} \Omega \mathrm{cm}$ at $25^{\circ} \mathrm{C}$ ) was used to prepare all solutions.

\subsection{Experimental procedure}


Electrochemical disinfection process was carried out using a commercial solid electrolyte electrolyzer (MIKROZON ${ }^{\circledR}$ ) supplied by CONDIAS GmbH (Itzehoe, Germany). This device is equipped with two boron doped diamond electrodes DIACHEM® $(15$ x $7.5 \mathrm{x}$ $0.725 \mathrm{~mm}^{3}$ ), which are synthetized on a structured silicon substrate. The electrodes are assembled into a single cell with a Fumasep ${ }^{\circledR}$ cation exchange membrane as solid electrolyte. This configuration is especially design to produce ozone during the electrolysis of water [15].

Synthetic urine polluted with $K$. pneumoniae was continuously recirculated from a cylindrical tank made of borosilicate to the electrochemical cell using a peristaltic pump (Percom N-M, JP Selecta) at a flowrate of $30 \mathrm{dm}^{3} \mathrm{~h}^{-1}$. The electric current was provided by a Delta Electronika ES030-10 power supply (0-30 V, 0-10 A), being the applied current intensities within the range 0.1-1.0 A. These values have been selected considering the limitations of the MIKROZON ${ }^{\circledR}$ cell: maximum current intensity: $1.2 \mathrm{~A}$; maximum voltage: $24 \mathrm{~V}$; maximum flow rate: $90 \mathrm{dm}^{3} \mathrm{~h}^{-1}$. All electrolyses were conducted in triplicate and under galvanostatic conditions. The initial volume of synthetic urine used was $1 \mathrm{dm}^{3}$.

The chemical composition of the simulated hospital urine was reported elsewhere [23]. This solution is intensified later with $K$. pneumoniae. The bacterial strain used was cultured in Tryptone Soy Agar plates (Scharlab S.L.) at $37^{\circ} \mathrm{C}$ for $24 \mathrm{~h}$ and resuspended into the synthetic urine up to an initial bacteria concentration of $10^{7} \mathrm{CFU} \mathrm{mL}^{-1}$.

\subsection{Biological analyses}


The $\mu$-Trac ${ }^{\circledR} 4200$ system was employed for counting the population of $K$. pneumoniae during the electrolysis tests. This is an indirect impedance method that uses a standard impedance signal (Media Impedance $=$ M-value) caused by the microbial metabolism. Low or non-charged nutrient molecules are metabolized during the growth of microorganisms. The analytical equipment records the impedance changes of the culture media from the breakdown of nutrients $[24,25]$. An initial calibration is needed to correlate the impedance values of standard samples with the concentration of the microorganisms in CFU mL $\mathrm{mL}^{-1}$ (plate counts).

Changes in cell wall permeability were monitored by the crystal violet assay [26]. Samples were firstly centrifugated at $5320 \times \mathrm{g}$ for $15 \mathrm{~min}$ to form a pellet which was resuspended in PBS containing $10 \mu \mathrm{g} \mathrm{ml}^{-1}$ of crystal violet and incubated at $37^{\circ} \mathrm{C}$ for 10 min. Then, the resulting mixture was centrifuged at $13400 \times \mathrm{g}$ for $15 \mathrm{~min}$ and the absorbance $\left(\mathrm{Abs}_{590}\right)$ of the supernatant was measured in a Biochrom Libra S70 spectrophotometer [27]. The $\mathrm{Abs}_{590}$ value of the crystal violet solution standard was considered as an uptake percentage of $100 \%$. The percentage uptake of crystal violet for each sample was calculated using the equation 1[28].

$$
\% \text { uptake }=\frac{\mathrm{Abs}_{\text {sample }}}{\mathrm{Abs}_{\text {crystal violet standard }}} \cdot 100
$$

Total concentration of protein was analysed following the procedure describe by Long et al. [29]. Cell lysis of the sample was conducted using the Bacterial Protein Extraction Reagent $\left(\mathrm{B}-\mathrm{PER}^{\circledR}\right)$, and then the total protein in the lysate was photochemically determined using the Pierce ${ }^{\mathrm{TM}}$ BCA Protein Assay Kit at $562 \mathrm{~nm}$. DNA concentration was determined according to the methodology reported in the literature [30, 31]. Samples were centrifuged at $5320 \times \mathrm{g}$ for 15 minutes to form the pellet. DNA was extracted from the pellet using a commercial Urine DNA Isolation Kit for Exfoliated Cells or Bacteria 
(Norgen Biotek). The amount of DNA was quantified by spectrophotometry at $260 \mathrm{~nm}$ using an ultra-Micro absorption cuvette $\left(\operatorname{Hellma}^{\circledR}\right)$.

\subsection{Chemical analyses}

Inorganic chloramines were determined using the DPD (N,N-diethyl-phenylenediamine) standard colorimetric method [32]. This is a selective analytical technique that avoids interferences of other oxidizing species formed during the process $\left(\mathrm{H}_{2} \mathrm{O}_{2}, \mathrm{O}_{3} \ldots\right)$. Inorganic ions were measured using a Metrohm 930 Compact IC Flex coupled to a conductivity detector equipment (ion chromatography). A Metrosep A Supp 7 and a Metrosep C6 250 columns were used for the analysis of anions and cations, respectively. Anions concentration was measured using a mobile phase of $85: 15 \mathrm{v} / \mathrm{v} 3.6 \mathrm{mM}$ $\mathrm{Na}_{2} \mathrm{CO}_{3}$ /acetone with a flow rate of $0.8 \mathrm{~cm}^{3} \mathrm{~min}^{-1}$ whereas a solution containing $1.7 \mathrm{mM}$ $\mathrm{HNO}_{3}+1.7 \mathrm{mM}$ 2,6-pyridinedicarboxylic acid with a flow rate of $0.9 \mathrm{~cm}^{3} \mathrm{~min}^{-1}$ was employed for cations measurement. The sample injection volume was $20 \mu \mathrm{L}$. Hypochlorite concentration was analyzed by titration with $0.001 \mathrm{M} \mathrm{As}_{2} \mathrm{O}_{3}$ in $2 \mathrm{M} \mathrm{NaOH}$ $[33,34]$. Ozone quantification was determined by an Ozone Test Spectroquant ${ }^{\circledR}($ Merk

KGaA, Germany). This test is based on the reaction of dipropyl-p-phenylenediamine with ozone to form a red-violet dye that is determined photometrically at $550 \mathrm{~nm}$. A Sension+ MM150 Portable Multi-Parameter Meter $(\mathrm{HACH})$ was used for the measurements of $\mathrm{pH}$ and conductivity.

\section{Results and discussion}


Fig. 1 shows the evolution of $K$. pneumoniae with the operation time during the electrolysis of urines at different current intensities using the MIKROZON® cell.

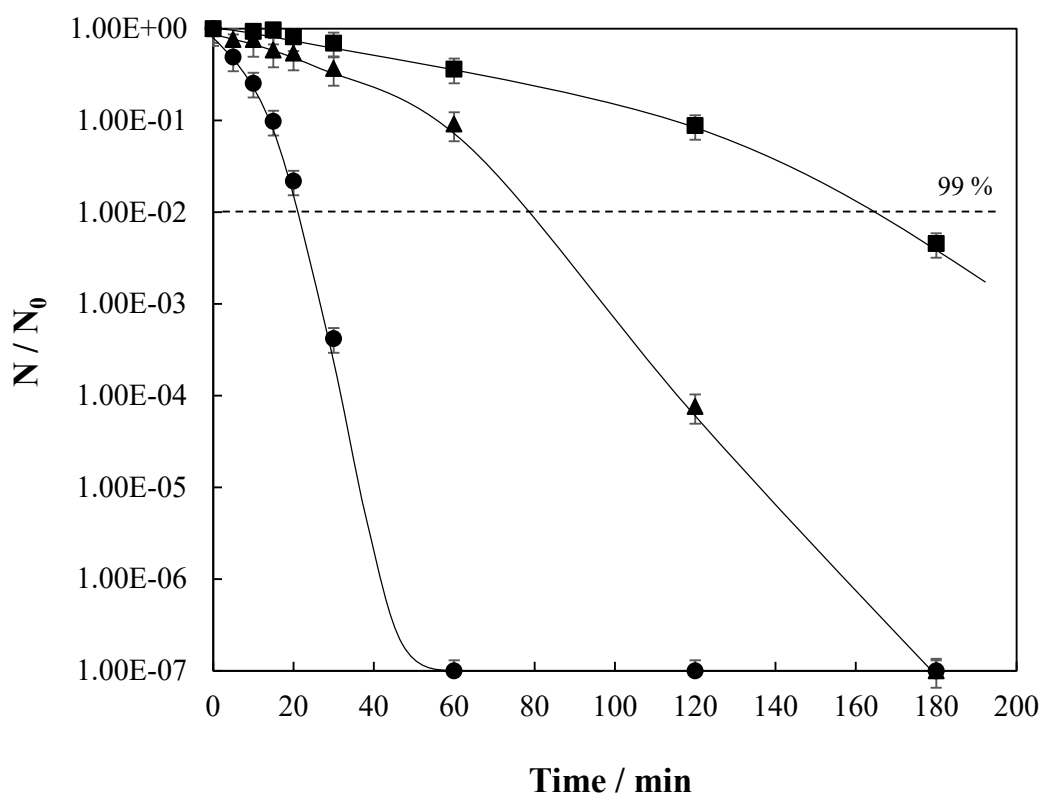

Fig. 1. Influence of the current intensity on the disinfection of urines using the MIKROZON® reactor. (曰) $0.1 \mathrm{~A} ;(\boldsymbol{\Delta}) 0.5 \mathrm{~A} ;(\bullet) 1.0 \mathrm{~A} ; \mathrm{N}_{0}: 10^{7} \mathrm{CFU} \mathrm{ml}^{-1}$.

As can be observed, it is possible to attain a complete disinfection of urines at operation times lower than 180 min when applying current intensities higher than $0.5 \mathrm{~A}$. This reveals that the current intensity clearly influences the process performance because the concentration of $K$. pneumoniae only decreases 2-logs at 0.1 A and the complete disinfection is achieved in 180 and $60 \mathrm{~min}$ at 0.5 and $1.0 \mathrm{~A}$, respectively. The higher is the current intensity applied, the higher is the removal rate. Furthermore, the removal efficiency also increases at higher current intensities since the applied electric charge required for killing microorganisms is $1.94 \mathrm{Ah} \mathrm{dm}^{-3}$ when working at $0.5 \mathrm{~A}$ and $1.21 \mathrm{Ah}$ $\mathrm{dm}^{-3}$ at 1.0 A. This is an unexpected behavior considering the previous results reported in literature, where the use of high current intensities during the electrolysis with diamond anodes leads to lower efficiencies due to the occurrence of undesirable 
parasitic/competitive reactions $[35,36]$. Hence, these results suggest that the nature and concentration of electrogenerated disinfectants with the MIKROZON ${ }^{\circledR}$ cell could play a key role on the removal of $K$. pneumoniae in urines. The mechanism of direct disinfection has been discarded because it mainly occurs when using porous materials where microorganisms can be retained [37].

Free and combined chlorine species are expected to be generated from the oxidation of chlorides contained in urine and the subsequent reaction with ammonium [23]. In addition, the MIKROZON® ${ }^{\circledR}$ cell used in this work is specially designed for the electrochemical production of ozone during the electrolysis which can also contribute to the disinfection process $[14,15]$. For this reason, the concentration of hypochlorite, chloramines and ozone were followed during the treatment at different current intensities and the results obtained is shown in Fig. 2. The concentration plotted in the figure refers to the free disinfectants that have not reacted yet, and it is expected that more disinfectants have been produced during the process but were consumed in the disinfection.
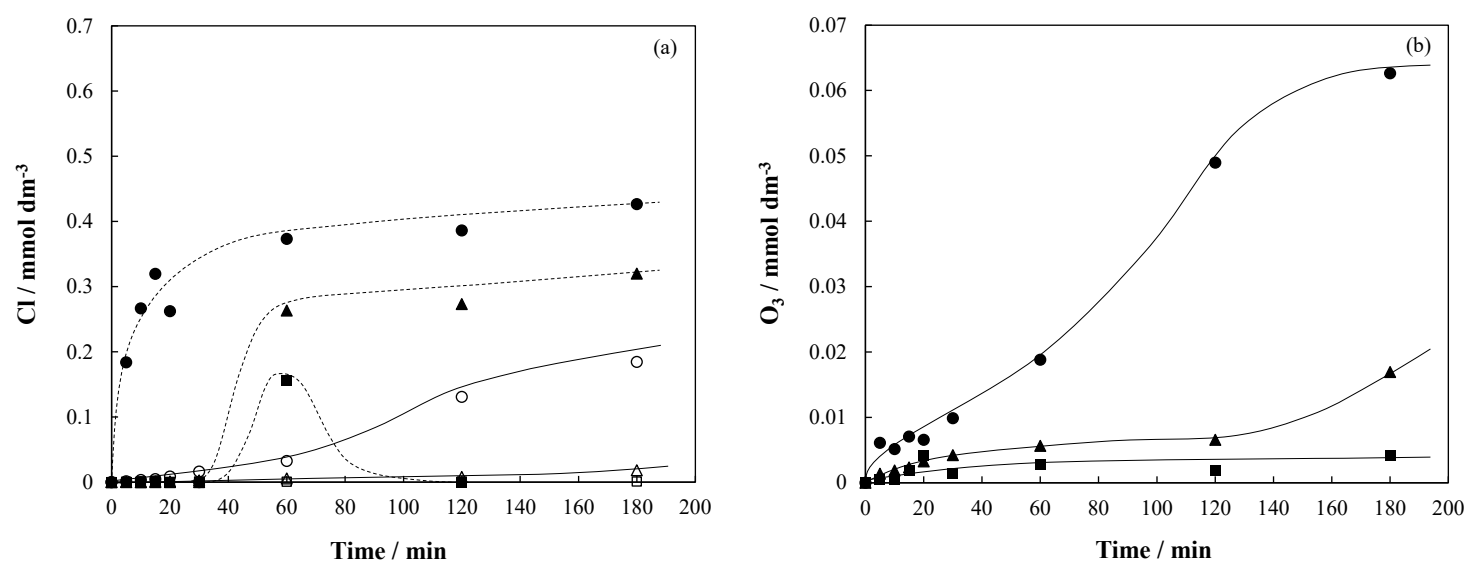

Fig. 2. Time course of the concentration of chlorine species (a) and ozone (b) electrogenerated during the disinfection of urines using the MIKROZON® reactor. Full

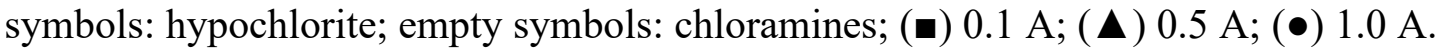


The concentration of hypochlorite increases with the operation time for all the tests carried out, although the maximum concentration is attained at $1.0 \mathrm{~A}\left(0.43 \mathrm{mmol} \mathrm{dm}{ }^{-3}\right.$ $\mathrm{Cl})$. At low current intensities $(0.1 \mathrm{~A})$, hypochlorite concentration shows a typical trend of intermediate compound: there is an initial increase followed by a decrease. On the other hand, hypochlorite increases drastically from $30 \mathrm{~min}\left(0.26 \mathrm{mmol} \mathrm{dm}^{-3} \mathrm{Cl}\right)$ and then, the production rate is reduced when applying $0.5 \mathrm{~A}$ (final concentration: $0.32 \mathrm{mmol} \mathrm{dm}{ }^{-3} \mathrm{Cl}$ ). A similar trend is observed at $1.0 \mathrm{~A}$, but the concentration of hypochlorite increases from the beginning of the experiment. Hypochlorite is a very reactive species which can react not only with microorganisms (disinfection) but also with other ions contained in the urine such ammonium, favoring the production of chloramines during electrolysis [38]. Furthermore, hypochlorite can also react with organics such as urea, creatinine, and uric acid but the evolution of these compounds will be discussed later.

The quantity of chloramines is negligible when working at $0.1 \mathrm{~A}$ because of the lower concentration of hypochlorite electrogenerated. At current intensities higher than $0.5 \mathrm{~A}$, these combined chlorine species increase with the operation time, reaching final concentrations of 0.02 and $0.18 \mathrm{mmol} \mathrm{dm}^{-3} \mathrm{Cl}$ at 0.5 and $1.0 \mathrm{~A}$, respectively. These values are lower than those obtained in free chlorine $\left(0.32\right.$ and $\left.0.43 \mathrm{mmol} \mathrm{dm}^{-3} \mathrm{Cl}\right)$ and reveal that chloramines could be consumed in the disinfection process or decomposed to chloride ions and nitrogen gas.

Regarding the ozone production during the electrodisinfection of urines (Fig. 2b), the concentration increases with the operation time and the current intensity applied. The maximum concentration of ozone was obtained when working at $1.0 \mathrm{~A}$, which is in line with the results obtained in chlorine speciation (Fig. 2a) and the disinfection rate (Fig. 1). Ozone values are one-fold lower than those obtained for free chlorine and this could mean that the removal of microorganisms is more affected by the attack of free and combined 
chlorine species instead ozone. However, the oxidation potential of ozone is higher than hypochlorite or chloramines $\left(\mathrm{E}^{0}: 2.07 \mathrm{~V} v s .1 .49 \mathrm{~V} ; 1.40 \mathrm{~V}\right)$ and it is expected than the disinfection capacity of this oxidant will be higher [18]. Therefore, the lower concentration of ozone measured in the liquid samples can be related to its lower stability in urine and to its higher reactivity.

Ozone and chlorine-based disinfectants seem to be the main responsible species for killing K. pneumoniae during the electrolysis of urines with the MIKROZON ${ }^{\circledR}$ cell but their disinfection mechanism can differ: disinfectant species can cause damage on the cell wall $[39,40]$ or directly penetrate inside the cell $[39,41]$ and destroy the genetic material. For this reason, to understand the role of disinfectants on the cell damage, the crystal violet assay was carried out. This allows us to check the changes in the cell wall through the uptake of the dye i.e., the cell wall permeability [27, 28, 42]. Fresh and treated urines were measured at the different current intensities studied to assess the combined effect of ozone and chlorine disinfectants on the cell damage. Fig. 3a shows the uptake of crystal violet by $K$. pneumoniae as function of the current intensity before and after the electrolysis of urines. Furthermore, to evaluate the single effect of electrogenerated ozone, the treatment of urines without chlorides were also carried out, where it is expected the production of ozone as main disinfectant. The crystal violet assay was also employed with this different urine matrix and results are presented in Fig. $3 b$.

As can be observed, the uptake of crystal violet decreases with the current intensity in both urine matrixes. This reveals that the cell wall is attacked by the electrogenerated disinfectants during the treatment. Cell changes seem to be more important at higher current intensities, which could be explained by the production of large amounts of disinfectants when increasing the current intensity in both matrixes. Likewise, the damage increases when treating urines containing chlorides for all the current intensities studied 
since the uptake of crystal violet decreases to a great extent in this urine matrix (Fig. 3a). Hence, the single effect of ozone on cell damage seems to be smaller than the combined effect with chlorine disinfectants. These results suggest that the main mechanism of the electrogenerated oxidants for killing bacteria could be the damage on the cell wall and, the subsequent attack to the genetic material. This agrees previous works reported in literature where the cell permeability during the electrochemical disinfection is evaluated and changes on cell wall were observed $[29,39,40,43]$.
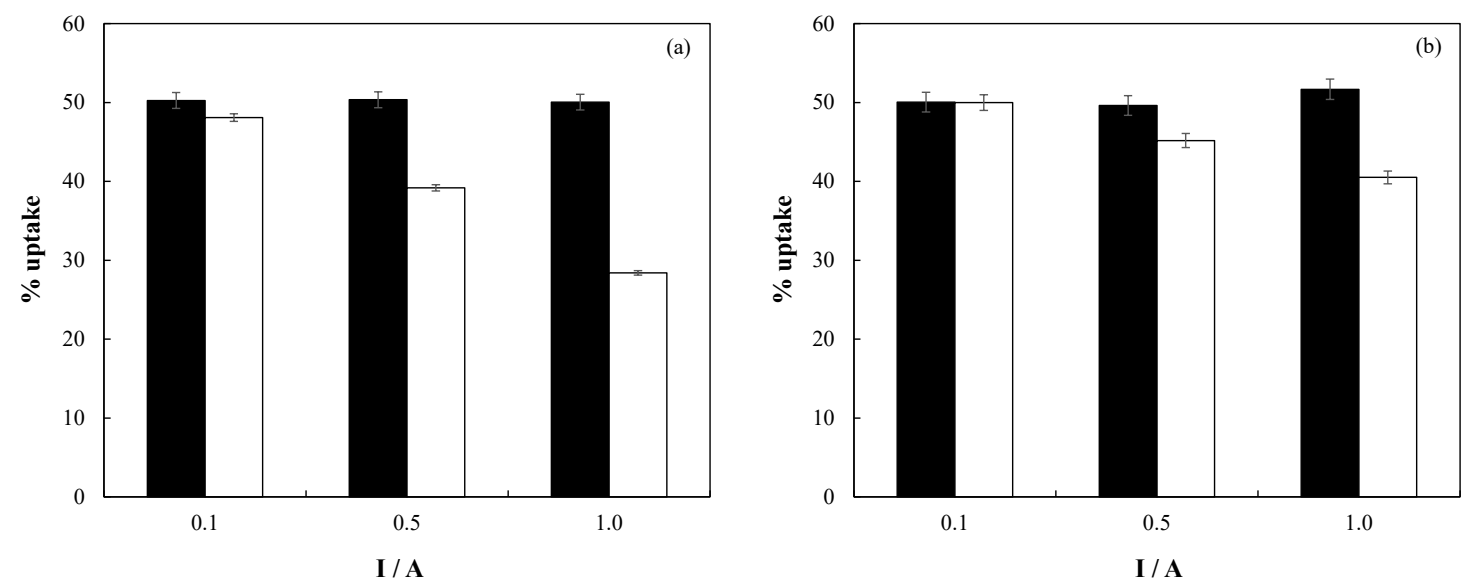

Fig. 3. Crystal violet uptake as function of the current intensity during the disinfection of urines using the MIKROZON® reactor. (a) Urine; (b) urine without chloride; (घ) fresh urine; ( $\square$ ) treated urine.

Proteins and genetic material (DNA) are needed for bacteria survival [44]. During the electrochemical treatment, electrogenerated disinfectants cause damages on cell wall (Fig. 3) and this could facilitate the pass of disinfectants into the cell, degrading the proteins and DNA [41]. For this reason, to shed light about the contribution of ozone and chlorine species on bacteria removal mechanisms, the evolution of total proteins and DNA concentrations were measured during the electrolysis of urines with and without 
chlorides. Fig. 4 shows the percentage removal of DNA and proteins achieved as function of the current intensity.

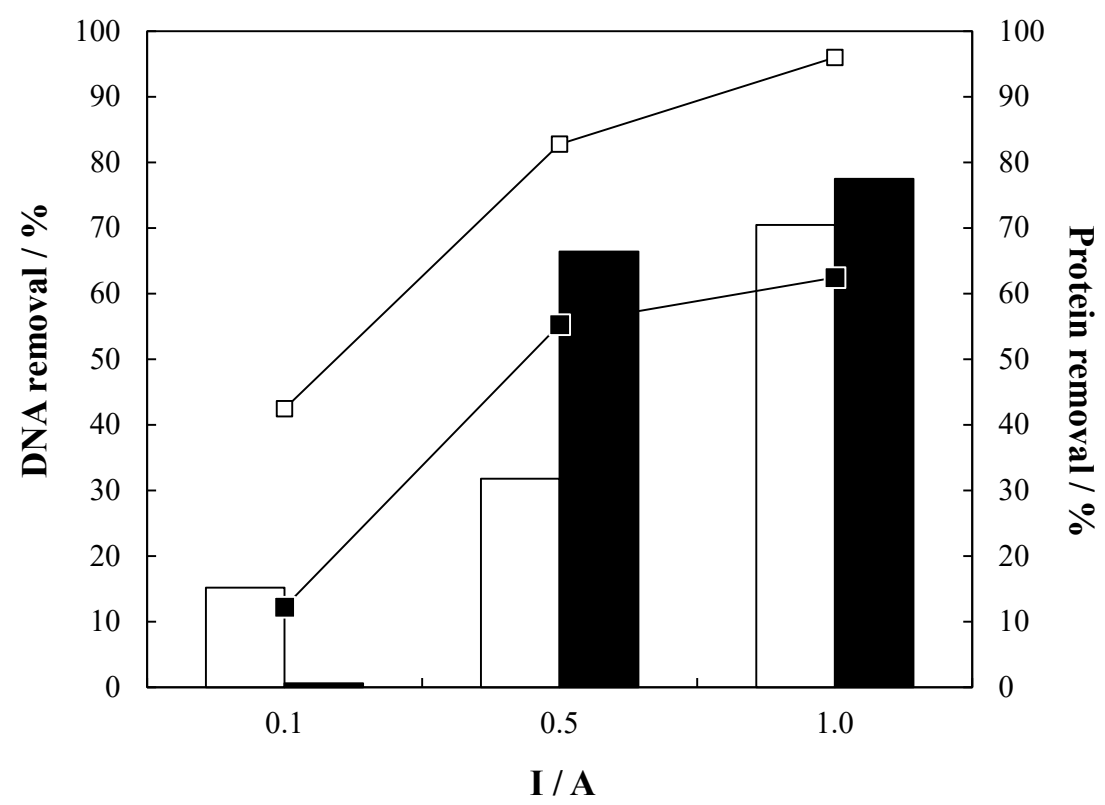

Fig. 4. DNA (bars) and protein concentration (points) removal as function of the current intensity during the disinfection of urines using the MIKROZON® reactor. ( $\square$ ) Urine; ( $\mathbf{a})$ urine without chloride.

As can be observed, the protein removal increases with the current intensity, being higher during the treatment of urine containing chlorides. Specifically, removal percentages higher than $80 \%$ were attained at current intensities above $0.5 \mathrm{~A}$ where bacteria had already been completely removed (Fig. 1) whereas values lower than $70 \%$ were achieved during the electrolysis of chloride-free urines. This reveals that the combined effect of ozone and chlorine-based disinfectants seems to favor the degradation of proteins during the electrolysis of urines using the MIKROZON® electrochemical cell.

Regarding the degradation of DNA, different behaviors can be seen depending on the current intensity applied. At $0.1 \mathrm{~A}$, a negligible DNA removal was obtained during the treatment of urines without chlorides, which could be related to a lower disinfection 
efficiency reached under these conditions. A DNA removal percentage of $15.18 \%$ was achieved when treating urines containing chlorides at $0.1 \mathrm{~A}$, where the removal of 2-log disinfection units was reached. Opposite to that, DNA removal is more remarkable during the treatment of chloride-free urines when applying current intensities higher than $0.5 \mathrm{~A}$. Specifically, removal percentages of 66.39 and $77.47 \%$ were obtained at 0.5 and $1.0 \mathrm{~A}$, respectively. The degradation of DNA is slightly higher than $30 \%$ during the electrolysis of urines with chlorides at $0.5 \mathrm{~A}$, which could be an unexpected outcome considering the complete removal of $K$. pneumoniae achieved under these conditions (Fig. 1). This suggests that DNA degradation seems to be more affected by the single effect of electrogenerated ozone. Finally, DNA removal percentages were quite similar when working at $1.0 \mathrm{~A}$, although the value obtained during the treatment of urines containing chlorides was slightly lower (70.46 vs. $77.47 \%)$. This confirms the potential effect of ozone on DNA degradation in comparison with the combined effect of ozone and chlorine-based disinfectants. Therefore, these results reveal that the combined effect of ozone and chlorine disinfectants promotes the degradation of proteins whereas single electrogenerated ozone seems to attack the DNA to a greater extent.

To shed light about the real contribution of ozone on the removal of $K$. pneumoniae, Fig 5a. compares the log removal units of $K$. pneumoniae during the electrolysis of urines with and without chlorides at different current intensities using the MIKROZON® cell. Likewise, the experimental data were fitted to a first order kinetics model [23] and the resulting rate constants for urine $\left(k_{\mathrm{U}}\right)$ and urine without chlorides $\left(k_{\mathrm{UWC}}\right)$ were also compared throughout the ratio $k_{\mathrm{U}} / k_{\mathrm{UwC}}$. Values higher than 1 indicate that the disinfection process is more efficient by the combination of electrogenerated chlorine and ozone disinfectants whereas ratios lower than 1 suggest a more contribution of ozone on the disinfection process. 

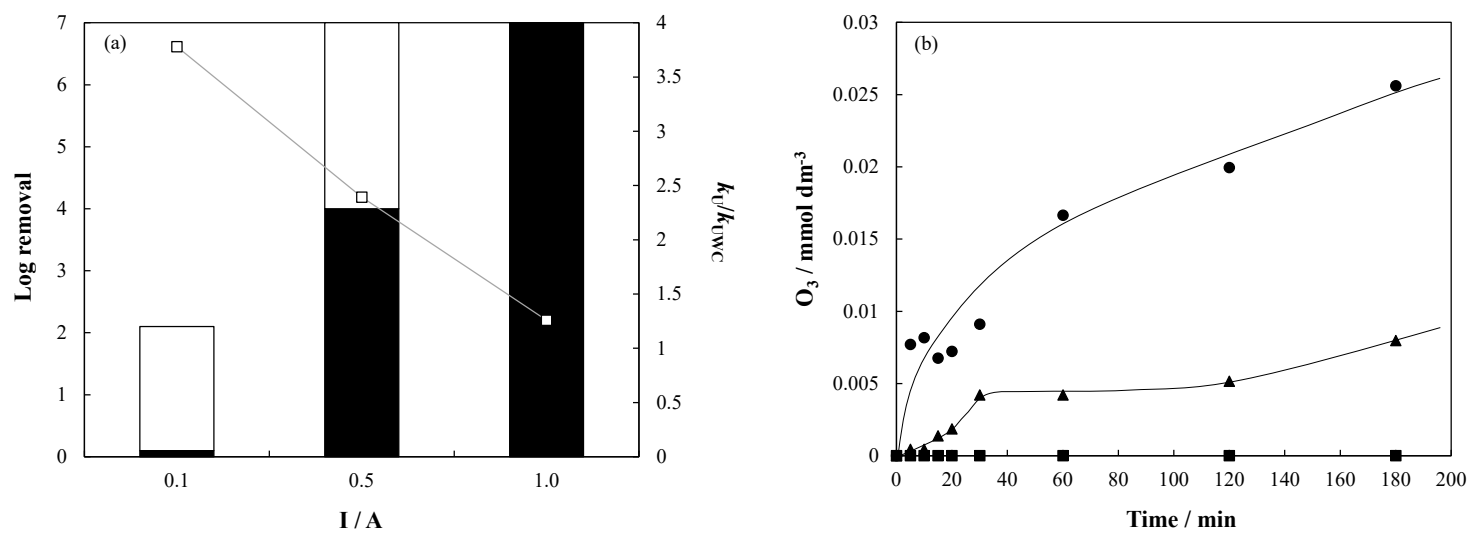

Fig. 5. (a) Log removal (bars) and ratio $k_{\mathrm{HU}} / k_{\mathrm{HUWC}}$ (points) as function of the current intensity; ( $\square$ ) urine; ( $\square$ ) urine without chlorides. (b) Time course of the concentration of ozone electrogenerated during the disinfection of urines without chlorides using the MIKROZON® reactor. $(\boldsymbol{\bullet}) 0.1 \mathrm{~A} ;(\boldsymbol{\Delta}) 0.5 \mathrm{~A} ;(\bullet) 1.0 \mathrm{~A}$.

As can be observed, a negligible disinfection was obtained during the treatment of urines without chlorides at 0.1 A. This can be related to the low concentration of electrogenerated ozone (Fig. 5b) under these conditions and the absence of chlorine-based disinfectants. In increasing the current intensity, the disinfection process becomes more efficient, reaching 4-logs removal at $0.5 \mathrm{~A}$ and the total disinfection when applying 1.0 A. On the other hand, the ratio $k_{\mathrm{U}} / k_{\mathrm{UwC}}$ decreases with the current intensity which suggests that the electrochemical disinfection based on the ozone production is limited at values lower than 1.0 $\mathrm{A}$ and it is required the combination of ozone and chlorine disinfectants to attain a complete removal of microorganisms at $0.5 \mathrm{~A}$. However, the ratio is close to 1 when the electrolysis is carried out at $1.0 \mathrm{~A}$. This means that the disinfection rates are quite similar either by the single effect of ozone or by the combined effect of ozone and chlorine disinfectants. Hence, it is necessary to apply current intensities of 1.0 A to produce large amounts of ozone with the MIKROZON® cell that assure the disinfection process in absence of chlorides. 
Finally, urine contains organic compounds which can be also oxidized during the electrolysis: urea, creatinine and uric acid [45]. The degradation of these organics can compete with the disinfection process and, for this reason, their concentrations were analyzed. Fig. 6a shows the evolution of urea, creatinine and uric acid as function of the operation time during the electrolysis of urines.
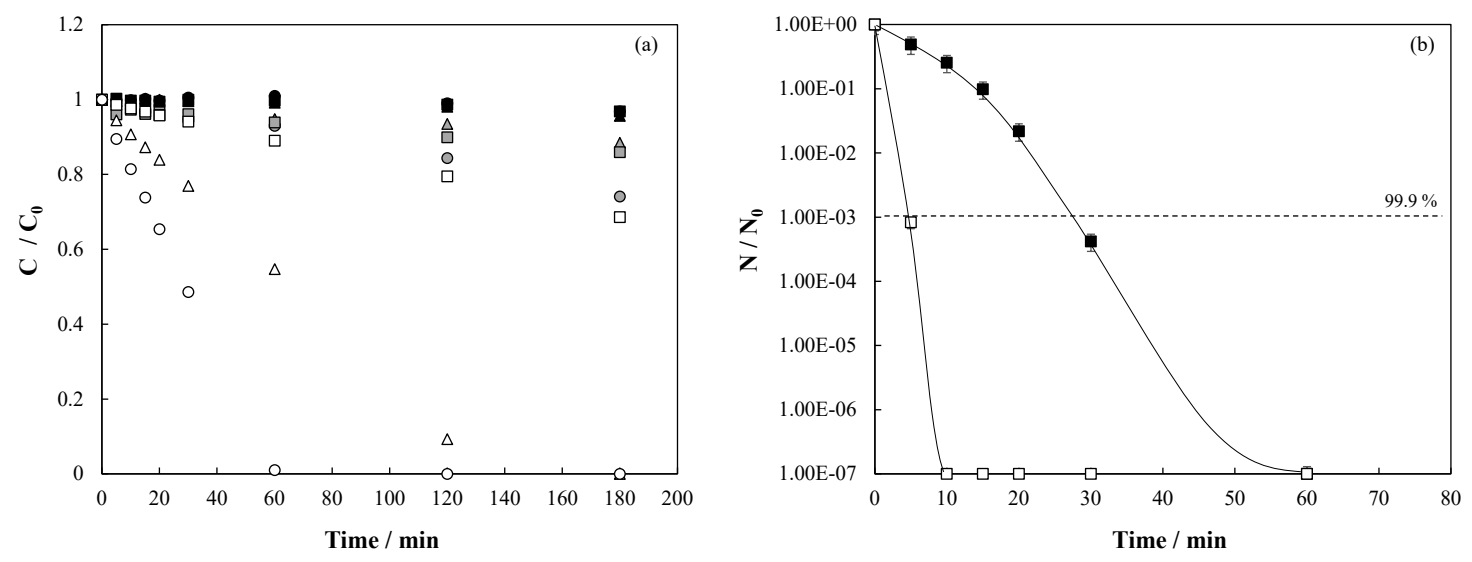

Fig. 6. (a) Time course of the concentration of organics during the disinfection of urines using the MIKROZON® reactor. Black symbols: urea; grey symbols: creatinine; white symbols: uric acid; (曰) $0.1 \mathrm{~A} ;(\boldsymbol{\Delta}) 0.5 \mathrm{~A} ;(\bullet) 1.0 \mathrm{~A}$. (b) Influence of urine matrix on the disinfection of urines using the MIKROZON® reactor at 1.0 A. (घ) hospital urine; ( $\square$ ) diluted (1:10) hospital urine.

The concentration of urea remains constant for all the tests carried out whereas creatinine slightly decreases, reaching a maximum percentage removal of $25.85 \%$ when working at 1.0 A. Furthermore, uric acid is completely removed from urine at current intensities higher than $0.5 \mathrm{~A}$. The different trends observed in each organic is mainly related to their initial concentration and molecular structure ([urea $]_{0}: 3333,34 \mathrm{mg} \mathrm{dm}^{-3}$; [creatinine $]_{0}$ : $166.67 \mathrm{mg} \mathrm{dm}^{-3}$; [uric acid] $0: 50 \mathrm{mg} \mathrm{dm}^{-3}$ ) [36]. This reveals that the lower the initial concentration, the higher the removal efficiency. Likewise, the molecular structures of uric acid and creatinine present more functional groups susceptible to be attacked by the 
disinfectants generated, favoring their degradation. These results point out that there exists a competitive oxidation between organics and components from bacteria during the electrolysis of urines that can be more remarkable at 1.0 A, because the organics removal percentages are higher. This is an expected behavior considering that higher current intensities lead to higher production of oxidants and, hence, higher organics degradation rates. To overcome the limitations related to competitive oxidation between organics and bacteria, the electrolysis of diluted urines was evaluated with the MIKROZON ${ }^{\circledR}$ cell, where the concentration of organics is ten times lower but the same bacteria concentration. This new formulation could be found in a real hospital effluent, once urine has been mixed with other grey waters from hospital and will allow us to evaluate the efficiency of the solid-electrolyte electro-ozonizer on the removal of $K$. pneumoniae with a small contribution of competitive reactions due to the lower organic load. Fig. $6 \mathrm{~b}$ shows changes in bacteria concentration during the disinfection of different urine matrixes at 1.0 A using the MIKROZON ${ }^{\circledR}$ cell.

As can be observed, a total disinfection of diluted urine is attained in 10 minutes whereas an operation time 6 times higher is required to guarantee the complete removal of $K$. pneumoniae in urines. The low initial concentration of organics in diluted urines ([urea $]_{0}$ : $333,34 \mathrm{mg} \mathrm{dm}^{-3}$; [creatinine] $0: 16.67 \mathrm{mg} \mathrm{dm}^{-3}$; [uric acid] $]_{0}: 5 \mathrm{mg} \mathrm{dm}^{-3}$ ) seems to promote higher disinfection rates (1.4194 vs. $\left.0.2194 \mathrm{~min}^{-1}\right)$. This confirms the occurrence of competitive reactions when treating urines with higher organic load. Likewise, the lower conductivity of diluted urines $\left(300 \mu \mathrm{S} \mathrm{cm}^{-1}\right)$ could favor the higher disinfection rates with the MIKROZON $®$ cell since this electrochemical device is specially designed for treating low conductivity waters [14]. These outcomes are great of interest because open the possibility of using a solid-electrolyte electro-ozonizer for treating hospital effluents where urine is diluted. 


\section{Conclusions}

The following conclusions can be drawn from this work:

- The use of a commercial electro-ozonizer allows to disinfect urines from current intensities higher than $0.5 \mathrm{~A}$. The disinfection rate is higher when increasing the current intensity due to the higher production of disinfectants.

- The electrochemical generation of ozone is promoted with the solid-electrolyte cell used. Likewise, free and combined chlorine species are generated from the oxidation of chlorides containing in urine. Both, ozone and chlorine-based disinfectants, contribute to the removal of $K$. pneumoniae. The electrogeneration of these species is clearly influenced by the current intensity. Large amounts of chlorine disinfectants are obtained in comparison with the ozone produced which can be related to the higher reactivity of the last one.

- The combined effect of ozone and chlorine disinfectants attains higher disinfection rates than the values obtained when single ozone is the main disinfectant electrogenerated (urine without chlorides) at current intensities lower than $0.5 \mathrm{~A}$. At values of $1.0 \mathrm{~A}$, the disinfection rates are quite similar which reveals that large amounts of ozone have been electrogenerated for the efficient removal of $K$. pneumoniae. The crystal violet assay shows that the combined effect of all disinfectants promotes higher cell damages, increasing the cell wall permeability.

- DNA and proteins are degraded during the disinfection of urines by electrochemical oxidation. The combined effect of ozone and chlorine disinfectants promotes the degradation of proteins for all the tests carried out. 
However, single electrogenerated ozone seems to attack the DNA to a greater extent from current intensities higher than $0.5 \mathrm{~A}$, where a remarkable disinfection rate is attained in urine matrixes without chlorides.

- Higher disinfection rates are obtained during the treatment of diluted urines by a solid-electrolyte electro-ozonizer at $1.0 \mathrm{~A}$. The occurrence of competitive reactions is minimized due to the lower organic load in the effluent. Furthermore, the low conductivity of diluted urines favors the removal of $K$. pneumoniae because the electrochemical cell is specially designed for the production of large amounts of ozone in low conductivity water.

\section{Acknowledgments}

Financial support from Junta de Comunidades de Castilla-La Mancha (JCCM), European Union (European Regional Development Fund), and Ministry of Science and Innovation through the projects SBPLY/17/180501/000396 and PID2019-110904RB-I00 are gratefully acknowledged. The Spanish Ministry of Economy, Industry, and Competitiveness and the European Union is also gratefully acknowledged through the project EQC2018-004469-P. Dr. Salvador Cotillas wishes to express his gratitude to the Spanish Ministry of Science, Innovation, and Universities for the "Juan de la CiervaIncorporación” post-doctoral grant (IJC2018-036241-I).

\section{References}


[1] E.D. Sunkari, H.M. Korboe, M. Abu, T. Kizildeniz, Sources and routes of SARS-

CoV-2 transmission in water systems in Africa: Are there any sustainable remedies?, Science of The Total Environment, 753 (2021) 142298.

[2] S. Kataki, S. Chatterjee, M.G. Vairale, S. Sharma, S.K. Dwivedi, Concerns and strategies for wastewater treatment during COVID-19 pandemic to stop plausible transmission, Resources, Conservation and Recycling, 164 (2021) 105156.

[3] B. Langlais, D.A. Reckhow, D.R. Brink, Ozone in Water Treatment: Application and Engineering, CRC Press2019.

[4] J.M. Dohan, W.J. Masschelein, The photochemical generation of ozone : present stateof-the-art, Ozone: Science \& Engineering, 9 (1987) 315-334.

[5] M. Steinberg, M. Beller, OZONE SYNTHESIS FOR WATER TREATMENT BY HIGH ENERGY RADIATION, Chem Eng Progr Symp Ser, 66 (1970) 205-220.

[6] G. Chen, Electrochemical technologies in wastewater treatment, Separation and Purification Technology, 38 (2004) 11-41.

[7] M. Panizza, G. Cerisola, Direct and mediated anodic oxidation of organic pollutants, Chemical Reviews, 109 (2009) 6541-6569.

[8] E. Lacasa, S. Cotillas, C. Saez, J. Lobato, P. Cañizares, M.A. Rodrigo, Environmental applications of electrochemical technology. What is needed to enable full-scale applications?, Current Opinion in Electrochemistry, 16 (2019) 149-156.

[9] P. Cañizares, C. Sáez, J. Lobato, R. Paz, M.A. Rodrigo, Effect of the operating conditions on the oxidation mechanisms in conductive-diamond electrolyses, Journal of the Electrochemical Society, 154 (2007) E37-E44.

[10] S. Cotillas, E. Lacasa, C. Sáez, P. Cañizares, M.A. Rodrigo, Disinfection of urine by conductive-diamond electrochemical oxidation, Applied Catalysis B: Environmental, 229 (2018) 63-70. 
[11] S. Cotillas, L. Cañizares, M. Muñoz, C. Sáez, P. Cañizares, M.A. Rodrigo, Is it really important the addition of salts for the electrolysis of soil washing effluents?, Electrochimica Acta, 246 (2017) 372-379.

[12] J.A. Lara-Ramos, J. Diaz-Angulo, F. Machuca-Martínez, Use of modified flotation cell as ozonation reactor to minimize mass transfer limitations, Chemical Engineering Journal, 405 (2021) 126978.

[13] J.A. Lara-Ramos, C. Saez, F. Machuca-Martínez, M.A. Rodrigo, Electro-ozonizers: A new approach for an old problem, Separation and Purification Technology, 241 (2020) 116701.

[14] J. Isidro, D. Brackemeyer, C. Sáez, J. Llanos, J. Lobato, P. Cañizares, T. Matthée, M.A. Rodrigo, Electro-disinfection with BDD-electrodes featuring PEM technology, Separation and Purification Technology, 248 (2020) 117081.

[15] J. Isidro, D. Brackemeyer, C. Sáez, J. Llanos, J. Lobato, P. Cañizares, T. Matthée, M.A. Rodrigo, Testing the use of cells equipped with solid polymer electrolytes for electro-disinfection, Science of the Total Environment, 725 (2020).

[16] S. Esplugas, D.M. Bila, L.G.T. Krause, M. Dezotti, Ozonation and advanced oxidation technologies to remove endocrine disrupting chemicals (EDCs) and pharmaceuticals and personal care products (PPCPs) in water effluents, Journal of Hazardous Materials, 149 (2007) 631-642.

[17] G. Boczkaj, A. Fernandes, Wastewater treatment by means of advanced oxidation processes at basic pH conditions: A review, Chemical Engineering Journal, 320 (2017) 608-633.

[18] C.P. Huang, C. Dong, Z. Tang, Advanced chemical oxidation: Its present role and potential future in hazardous waste treatment, Waste Management, 13 (1993) 361-377. 
[19] C.L. Ventola, The antibiotic resistance crisis: part 1: causes and threats, P T, 40 (2015) 277-283.

[20] J. Oh, D.E. Salcedo, C.A. Medriano, S. Kim, Comparison of different disinfection processes in the effective removal of antibiotic-resistant bacteria and genes, J. Environ. Sci., 26 (2014) 1238-1242.

[21] C. Stange, J.P.S. Sidhu, S. Toze, A. Tiehm, Comparative removal of antibiotic resistance genes during chlorination, ozonation, and UV treatment, International Journal of Hygiene and Environmental Health, 222 (2019) 541-548.

[22] S. Rodriguez-Mozaz, S. Chamorro, E. Marti, B. Huerta, M. Gros, A. SànchezMelsió, C.M. Borrego, D. Barceló, J.L. Balcázar, Occurrence of antibiotics and antibiotic resistance genes in hospital and urban wastewaters and their impact on the receiving river, Water Research, 69 (2015) 234-242.

[23] M. Herraiz-Carboné, S. Cotillas, E. Lacasa, P. Cañizares, M.A. Rodrigo, C. Sáez, Enhancement of UV disinfection of urine matrixes by electrochemical oxidation, Journal of Hazardous Materials, (2020).

[24] J. Dupont, F. Dumont, C. Menanteau, M. Pommepuy, Calibration of the impedance method for rapid quantitative estimation of Escherichia coli in live marine bivalve molluscs, Journal of Applied Microbiology, 96 (2004) 894-902.

[25] S. Zhu, S. Schnell, M. Fischer, Rapid detection of Cronobacter spp. with a method combining impedance technology and rRNA based lateral flow assay, Int. J. Food Microbiol., 159 (2012) 54-58.

[26] M. Vaara, T. Vaara, Outer membrane permeability barrier disruption by polymyxin in polymyxin-susceptible and-resistant Salmonella typhimurium, Antimicrobial agents and chemotherapy, 19 (1981) 578-583 
[27] K.P. Devi, S.A. Nisha, R. Sakthivel, S.K. Pandian, Eugenol (an essential oil of clove) acts as an antibacterial agent against Salmonella typhi by disrupting the cellular membrane, Journal of Ethnopharmacology, 130 (2010) 107-115.

[28] S.J. Ahmad, H.H. Lian, D.F. Basri, N.M. Zin, Mode of action of endophytic Streptomyces sp., SUK 25 extracts against MRSA; microscopic, biochemical and timekill analysis, Int. J. Pharm. Sci. Rev. Res, 30 (2015) 11-17.

[29] Y. Long, J. Ni, Z. Wang, Subcellular mechanism of Escherichia coli inactivation during electrochemical disinfection with boron-doped diamond anode: A comparative study of three electrolytes, Water Research, 84 (2015) 198-206.

[30] K.A. Alexander, C.E. Sanderson, M.H. Larsen, S. Robbe-Austerman, M.C. Williams, M.V. Palmer, Emerging tuberculosis pathogen hijacks social communication behavior in the group-living banded mongoose (Mungos mungo), MBio, 7 (2016).

[31] K.L. Nielsen, P. Dynesen, P. Larsen, L. Jakobsen, P.S. Andersen, N. Frimodt-Møller, Role of urinary cathelicidin LL-37 and human $\beta$-defensin 1 in uncomplicated Escherichia coli urinary tract infections, Infection and Immunity, 82 (2014) 1572-1578.

[32] A. WPCF, APHA, Standard Methods for the Examination of Water and Wastewater, 20th Ed, American Public Health Association (APHA), Washington DC, (1998).

[33] A.v. Wilpert, Über die Analyse von Hypochlorit und Chlorit in einer Lösung, Z. Anal. Chem., 155 (1957) 378-378.

[34] H. Freytag, Zur Bestimmung von Hypochlorit, Chlorid und Chlorat in Chlorkalk, Z. Anal. Chem., 171 (1959) 458-458.

[35] M. Panizza, G. Cerisola, Application of diamond electrodes to electrochemical processes, Electrochimica Acta, 51 (2005) 191-199. 
[36] S. Cotillas, E. Lacasa, C. Sáez, P. Cañizares, M.A. Rodrigo, Removal of pharmaceuticals from the urine of polymedicated patients: A first approach, Chemical Engineering Journal, 331 (2018) 606-614.

[37] H. Liu, X.-Y. Ni, Z.-Y. Huo, L. Peng, G.-Q. Li, C. Wang, Y.-H. Wu, H.-Y. Hu, Carbon Fiber-Based Flow-Through Electrode System (FES) for Water Disinfection via Direct Oxidation Mechanism with a Sequential Reduction-Oxidation Process, Environmental Science \& Technology, 53 (2019) 3238-3249.

[38] S. Cotillas, J. Llanos, I. Moraleda, P. Cañizares, M.A. Rodrigo, Scaling-up an integrated electrodisinfection-electrocoagulation process for wastewater reclamation, Chemical Engineering Journal, 380 (2020).

[39] H. Li, X. Zhu, J. Ni, Comparison of electrochemical method with ozonation, chlorination and monochloramination in drinking water disinfection, Electrochimica Acta, 56 (2011) 9789-9796.

[40] H.F. Diao, X.Y. Li, J.D. Gu, H.C. Shi, Z.M. Xie, Electron microscopic investigation of the bactericidal action of electrochemical disinfection in comparison with chlorination, ozonation and Fenton reaction, Process Biochemistry, 39 (2004) 1421-1426.

[41] H. Li, Z. Zhang, J. Duan, N. Li, B. Li, T. Song, M.F. Sardar, X. Lv, C. Zhu, Electrochemical disinfection of secondary effluent from a wastewater treatment plant: Removal efficiency of ARGs and variation of antibiotic resistance in surviving bacteria, Chemical Engineering Journal, 392 (2020) 123674.

[42] M. Vaara, T. Vaara, Outer Membrane Permeability Barrier Disruption by Polymyxin in Polymyxin-Susceptible and -Resistant $<$ em $>$ Salmonella typhimurium $</$ em $>$, Antimicrobial Agents and Chemotherapy, 19 (1981) 578-583. 
[43] C. Bruguera-Casamada, I. Sirés, M.J. Prieto, E. Brillas, R.M. Araujo, The ability of electrochemical oxidation with a BDD anode to inactivate Gram-negative and Grampositive bacteria in low conductivity sulfate medium, Chemosphere, 163 (2016) 516-524. [44] T.D. Brock, M.T. Madigan, J.M. Martinko, J. Parker, Brock biology of microorganisms, Upper Saddle River (NJ): Prentice-Hall, 2003.2003.

[45] M. Herraiz-Carboné, S. Cotillas, E. Lacasa, Á. Moratalla, P. Cañizares, M.A. Rodrigo, C. Sáez, Improving the biodegradability of hospital urines polluted with chloramphenicol by the application of electrochemical oxidation, Science of the Total Environment, 725 (2020). 